\title{
Pendidikan Multikultural Di Masyarakat
}

\author{
${ }^{1 .}$ Hasbullah , ${ }^{2 .}$ Nurhasanah \\ 1.2. Universitas Muhammadiyah Pringsewu \\ 1. hasbullah@umpri.ac.id, ${ }^{2 .}$ khazanah@umpri.ac.id
}

\begin{abstract}
One of the objects of education is society. Education in society is certainly different from education in schools. This education is carried out in order to maintain differences and not without these differences. So that the formulation of multicultural education is a solution and can be applied in a society with very complex problems. This research will discuss about what is multicultural education and multicultural society. How to give birth to multicultural schools and differences in society. This study uses a qualitative descriptive approach, with the type of literature study. Literature research is carried out through books, magazines, journals, internet and so on. In addition, by conducting research from previous studies. The results found from this study are; That multicultural education in society will produce a society that is ready to accept differences, a society that is critical and socially concerned, creates unity and minimizes radicalism, and builds a moral commitment to mutual respect and tolerance.
\end{abstract}

Keywords: Multicultural Education, Society

\begin{abstract}
ABSTRAK
Salah satu obyek pendidikan adalah masyarakat. Pendidikan di masyarakat tentunya berbeda dengan pendidikan di sekolah. Pendidikan ini dilaksakan dalam rangka menjaga perbedaan dan bukan memaksakan menyatukan perbedaan tersebut. Maka formula pendidikan multikulural, menjadi solusi dan dapat diterapkan di tengan masyarakat yang sangan komplek permasalahnya. Penelitian ini akan membahas tentang apa itu pendidikan mulitkulural dan masyarakat mulitikulural. Bagaimana melahirkan sekolah multikulural dan merawat perbedaan di maysarakat. Penelitian ini menggunakan pendekatan penelitian deskriptif kualitatif, dengan jenis penelitian studi pustaka. Penelitian kepustakaan di lakukan melalui buku, majalah, jurnal, internet dan sebagainya. Selain itu dengan melakukan studi pengamatan dari penelitian-penelitian sebelumnya. Hasil yang ditemukan dari penelitian ini yaitu; Bahwa Pendidikan multikulural di tengah masyarakat akan menghasilakan masyarakat yang siap dengan perbedaan, masyarakat yang kritis dan tingginya kepedulian sosial, melahirkan persatuan dan meminimalisir radikalisme, serta menguatkan ikatan komitmen moral untuk saling menghargai dan toleransi.
\end{abstract}

Kata kunci : Pendidikan Multikultural, Masyarakat 


\section{PENDAHULUAN}

Masyarakat merupakan obyek dari pendidikan itu sendiri termasuk di dalamnya pendidikan multikultural. Perlu juga kita fahami bahwa pendidikan tidak dapat berdiri sendiri, kegiatan dan aktivitas pendidikan sangat terkait dengan pihak-pihak lain. Ada tiga isntitusi pendidikan yaitu sekolah, keluarga dan masyarakat. Adapun pendidikan multikultural tidak bisa terlepas dari trilogi isntitusi tersebut semuanya akan saling berkerjasama dalam pelaksanaan dan juga dalam melakukan perubahan peserta didik untuk menghadapi masa depan yang perubahannya sangat dinamis dan transformatif.

Pedidikan merupakan proses memanusiakan manusia secara berkelanjutan dan terarah dalam mempersiapkan peserta didik dalam menghadapi semua proses kehidupan di masyarakat. Sedang masyarakat akan senantiasa berubah-ubah sesuai dengan perubahan zaman, karena masyarakat akan sangat terpengaruhi oleh tempat dan keadaan. Dalam perubahan-perubahan di masyarakat tersebutlah pendidikan dituntut jeli melihat itu semua, agar idealnya serta porsi pendidikan tidak ikut larut dalam perubahan akan tetapi pendidikan akan mewarnai perubahan masyarakat tersebut. Pendidikan multikultural menjadi salah satu alternatife dalam merespon perubahan-perubahan pada masyarakat, terlebih dalam merawat kemajemukan yang terjadi dalam interaksi serta pergulatan kemasyarakatan.

Di sisi lain dalam kehidupan sehari-hari, bahwa kebudayaan sukubangsa dan kebudayaan agama, bersama-sama dengan pedoman kehidupan berbangsa dan bernegara, mewarnai perilaku dan kegiatan kita. Berbagai kebudayaan itu berseiringan, saling melengkapi dan saling mengisi, tidak berdiri sendiri-sendiri bahkan mampu untuk saling menyesuaikan (fleksibel) dalam percaturan hidup sehari-hari (Lasijan, 2014: 26).

Lebih dalam dapat kita lihat dan pahami bawah kelangsungan dan berkembangnya kebudayaan lokal perlu dijaga dan dihindarkan dari hambatan. Unsur-unsur budaya lokal yang bermanfaat bagi diri sendiri bahkan perlu dikembangkan lebih lanjut agar dapat menjadi bagian dari kebudayaan bangsa, memperkaya unsur-unsur kebudayaan nasional. Meskipun demikian, sebagai kaum profesional Indonesia, misi utama kita adalah mentransformasikan kenyataan multikultural sebagai aset dan sumber kekuatan bangsa, menjadikannya suatu sinergi nasional, memperkukuh gerak konvergensi, keanekaragaman (Nur Syam, 2009: 67).

Pendidikan multikultural memandang bahwa dalam masyarakat serting terjadi penyimpangan yang berpontensi konflik besar sehingga ini harus menjadi pemikiran 
dalam melakukan langka preventif agar tidak terjadi konflik, kalaupun terjadi konflik itu hanya pada ranah diskusi yang tujuannya untuk memajukan nilai-nilai kemasyarakatan yang berlaku. Maka pendidikan multikultural akan sangat membantu dalam merawat masyarakat multikultural yang ada, dengan cara mendidik peserta didik dalam nuansa dan suasana pendidikan multikultural menghargai perbedaan dan menikmati keragaman baik itu prilaku maupun pemikiran.

Multikulturalisme sebagai gagasan yang menyatakan bahwa tidak ada perbedaan status sosial dari berbagai kalangan dan kebudayaan dalam satu cakupan wilayah merupakan bahan kajian yang selalu menarik untuk diperbincangkan, terlebih jika wilayahnya mencakup sebuah negara plural seperti Amerika dan Indonesia. Ketika konsep multikulturalisme benar-benar menyentuh keberagaman dalam sebuah negara yang menuntut adanya persatuan dan kesatuan di satu sisi secara menyeluruh namun terbentur pada kepentingan kesejahteraan kelompok secara parsial di sisi lain, perlu adanya sebuah upaya pendekatan lain terhadap nilai-nilai multikulturalisme yang ingin dicapai selain dengan kebijakan kekuasaan politik yang terkesan memaksa maupun kacamata sejarah yang rawan konflik (Stella Rose Que, 2017: 87) .

Adapa penelitian ini mencoba mendedah dengan pendekatan literatul tentang pendidikan multikultura di Tengah masyarakat. Sehingga dari sini akan melahirkan pemikiran dalam memperjelas dan menguatkan dalam mendesain pendidikan yang dapat memberikan sumbangsih pemikiran tentang pendidikan multikultural dan masyarakat multikultural. Sehingga kajian penelitian ini akan terfokus pada apa itu pendidikan multikulural dan masyarakat multikulural, serta bagaimana konsep sekolah multikulurtal dan merawat multikulural di masyarakat.

\section{METODE PENELITIAN}

Adapaun penelitian ini menggunakan jenis penelitian kualitatif non interaktif dengan menggunakan metode analisis konsep/isi (teks). Sebab penelitian yang dilakukan adalah meneliti setiap teks/isi yang terdapat dalam beberapa buku dan jurnal yang berhubungan dengan pendidikan multikulutal di Tengah masyarakat. Jenis data dalam penelitian ini merupakan gambaran umum tentang apa itu pendidikan mulitkultural dan masyarkat mulitikulural serta bagaimana mendesain sekolah multikulural dan merawat perbedaan di Tengah masyarakat. Sehingga kita akan memahami konsep, kedudukan dan penerapan pendidikan multikulural di Tengah masyarakat. 
Sumber data yang digunakan dalam penelitian ini menggunakan dua sumber yaitu primer dan sekunder. Data primer berupa beberapa jurnal yang berkaitan dengan kajian yang sedang ditulis dan data sekunder yang diambil dari buku-buku tentang pendidikan multikulral di masyarakat. Dengan dua data ini akan terlihat dengan jelas letak dan posisi pendidikan multikulural di Tengah masyarakat.

Data yang telah dikumpulkan selanjutnya dianalisis dengan baik menggunakan metode analisis isi (Content Analysis). Analisis ini dikembangkan sebagai upaya penggalian lebih lanjut mengenai kajian dalam penelitian ini.

\section{HASIL DAN PEMBAHASAN}

\section{a. Pendidikan Multikultural}

Paulo Freire berpendapat pendidikan bukan merupakan "menara gading" yang berusaha menjauhi realitas sosial dan budaya. Pendidikan menurutnya, harus mampu menciptakan tatanan masyarakat yang terdidik dan berpendidikan, bukan sebuah masyarakat yang hanya mengagungkan prestise sosial sebagai akibat kekayaan dan kemakmuran yang dialaminya. Pendidikan multikultural (multicultural education) merupakan respon terhadap perkembangan keragaman populasi sekolah, sebagaimana tuntutan persamaan hak bagi setiap kelompok (Paulo, 1984:102). Dan secara luas pendidikan multikultural itu mencakup seluruh siswa tanpa membedakan kelompokkelompoknya seperti gender, etnik, ras, budaya, strata sosial dan agama. Pendidikan multikultural merupakan proses pengembangan seluruh potensi manusia yang menghargai pluralitas dan heter oginitasnya sebagai konsekwensi keragaman budaya, etnis, suku, dan aliran (agama) (Ainurrafiq Dawam, 2003: 54).

Dengan demikian bahwa pendidikan multikultural adalah upaya untuk mengeluarkan segala potensi yang dimiliki oleh manusia sehingga menghasilakan prestasi berdasarkan kemampuan yang dimiliki. Selain itu pendidikan multikultural mendesain dunia pendidikan untuk dapat menikmati perbedaan dan keragaman yang dimiliki manusia terutama dalam dunia pendidikan, sehingga pendidikan akan lebih bernuasa, kaya akan narasi kebersamaan dan kesatuan.

Pendidikan multikultural dapat pula diartikan sebagi sebuah strategi pendidikan yang diaplikasikan pada semua jenis mata pelajaran dengan cara mengunakan perbedaanperbedaan kultural yang ada pada siswa seperti perbedaan etnis, agama, bahasa, gender, kelas sosial, ras, kemampuan, dan umur agar supaya proses belajar menjadi efektif dan 
mudah serta sekaligus untuk melatih dan membangun karakter siswa agar mampu untuk selalu bersikap demokratis, humanis dan pluralis dalam keberagaman yang ada di lingkungannya baik di sekolah maupun di luar sekolah (M. Ainul Yaqin, 2005: 3).

Kamanto Sunarto berpendapat, "Pendidikan multikultural biasa diartikan sebagai pendidikan keragaman budaya dalam masyarakat, dan terkadang juga diartikan sebagai pendidikan yang menawarkan ragam model untuk keragaman budaya dalam masyarakat, dan terkadang juga diartikan sebagai pendidikan untuk membina sikap siswa agar menghargai keragaman budaya masyarakat”. (Kamanto Sunarto,2004)

Pendidikan multikultural merupakan salah satu alternative dari pendidikan yang selama ini dijalankan, karena pendidikan bukan saja hanya transfer pengetahuan melainkan transfer kebaikan prilaku dan memperlakukan hidup dengan benar tanpa memandang dan mempermasalahkan perbedaan. Dengan pendidikan multikultural dengan sendiri karakter siswa terbangun dengan baik karena terjadi asimilasi budaya dan interaksi pemikiran tanpa bantas.

Fakta sosial yang terjadi juga menunjukkan bahwa fenomena keragaman bahwa sangat sulit untuk menerapkan mutikultural walaupun sudah dipaparakan dalam dunia pendidikan dalam bentuk pendidikan multikultural. Dalam kehidupan sosial masih banyak masyarakat termasuk di dalamnya orang-orang yang memiliki pengatahuan lebih belum siap hidup dalam perbedaan pemahaman. Permasalahan yang selalu menyertai dalam pengimplementasian pendidikan multikultural sangat berdimensi dan beragama, sehingnya perlu sekali bagi kita semua untuk melihat dimensi-dimensi yang harus dipahami dalam implemnetasi pendidikan multikultural.

Dalam pendidikan multikultural, ada dimensi-dimensi yang harus diperhatikan. Sebagaimana yang dijelaskan oleh James Blank ada lima dimensi pendidikan multikultural yang saling berkaitan, yaitu sebagai berikut: 1). Mengintegrasikan berbagai budaya dan kelompok untuk mengilustrasikan konsep mendasar, generalisasi, dan teori dalam mata pelajaran. 2). Membawa siswa untuk memahami implikasi budaya ke dalam sebuah mata pelajaran. 3). Menyesuaikan metode pengajaran dengan cara belajar siswa dalam rangka memfasilitasi prestasi akademik. 4). Mengidentifikasi karakteristik ras siswa dan menentukan metode pengajarannya. 5). Melatih kelompok untuk berpartisipasi dalam berbagai kegiatan, berinteraksi dengan seluruh siswa dan staf yang berbeda ras dan etnis untuk menciptakan budaya akademik. 
Selain dimensi juga harus memahami hal yang penting dalam implementasi harus mengetahui unsur dari pendidikan multikultural, unsur utama dalam pendidikan multikultural adalah penempatan posisi siswa sebagai subyek yang bersifat sejajar. Terlihat dari dari unsur pendidikan multikultural bahwa tidak ada siswa menjadi superioritas dan dipriotitaskan, melainkan siswa diperlakukan sama baik dan juga memiliki kesamaan antara siswa dengan siswa lainnya dalam hal kultural (A. Fuad Fanani, 2004).

Semakin kuatlah argumentasi bawah pendidikan multikultural dapat melatih dan membangun karakter siswa yaitu karakter mampu bersikap demokratis, humanis dan pluralis dalam lingkungan mereka terutama dalam dunia pendidikan. Dari sinilah Pendidikan multikultural memiliki posisi strategis dalam memberikan sumbangsih terhadap penciptaan perdamaian dan upaya penanggulangan konflik. Dengan sendirinya penanaman dan pembumian nilai toleransi, empati, simpati dan solidaritas sosial berajalan sebagai nilai-nilai dasar dari pendidikan.

\section{b. Masyarakat Multikultural}

Kita semua memahami bahwa istilah masyarakat tidak asing lagi didengar. Dalam setiap wilayah memiliki anggota masyarakata yang menganut budaya, adat istiada yang berbeda-beda yang itu semua dibangun sebagai acuan dalam meneguhkan masyarakat agar tetap baik secara indentitas baik secara nilai maupun moral baik secara individu maupun kelompok. Dengan perbedaan masyarakat ini sebenarnya adalah hal yang dapat dijadikan kekuatan dalam membangun peradaban yang baik.

Masyarakat adalah suatu sistem dari kebiasaan dan tata cara, wewenang dan kerja sama antara berbagai kelompok dan penggolongan dan pengawasan tingkah laku serta kebebasan-kebebasan manusia secara keseluruhan dan selalu berubah (Nurani Soyomukti, 2010: 1). Masyarakat adalah golongan besar atau kecil yang terkumpul dari beberapa manusia, dengan atau karena sendirinya, saling bertalian secara golongan dan mempunyai pengaruh kebatinan antara mansuia yang satu dengan manusia lainnya (Abu Ahmadi, 2009: 2)

Ciri-ciri masyarakat adalah sebagai berikut : 1). Masyarakat merupakan sekumpulan manusia yang hidup bersama. Tingkatan hidup bersama ini bisa dimulai dari dua kelompok. 2). Hidup bersama untuk waktu yang cukup lama. Dalam hidup bersama ini, akan terjadi interaksi antara manusia-manusia yang ada dalam kelompok masyarakat. Interakasi ini akan berlangsung secara terus menerus tanpa henti dan akan melahirkan 
sistem interaksi yang akan tampak dalam peraturan-peraturan yang akan mengatur hubungan antar manusia. 3). Mereka sadar bahwa mereka merupakan satu kesatuan yang saling melengkapi dan saling membutuhkan satu dengan yang lainnya. 4). Mereka merupakan suatu sistem hidup bersama, sistem kehidupan bersama menimbulkan kebudayaan karena setiap anggota kelompok merasa dirinya terkait satu dengan lainya (Soerjono Soekanto, 2012: 36).

Berdasarkan padangan di atas, pemakalah menambahkan bahwa masyarakat adalah komunitas yang berada disuatu tempat telah terjalin dalam waktu dan keadaan cukup lama serta terjadinya asimilasi baik itu pemikiran, budaya dan adat istiadat. Sedang terkait dengan ciri masyarakat menurut pemakalah adalah mereka yang berada disuatu daerah yang saling membantu, saling mengingatkan dan memiliki aturan dalam kehidupan kebudayaan serta adat istiadat yang berlaku dalam daerah tersebut.

Maka masyarakat adalah elemen yang di dalamnya begitu banyak perbedaan yang bukan hanya untuk disatukan tetapi bagaimana dirawat dan menjadi kekuatan untuk meningkatkan kualitas kehidupan baik dalam prilaku maupun pemikiran. Maka dalam padangan pemakalah masyarakat itu sudah multikultural yang ada sejak awal dan sudah berjalan, yang hal ini harus dirawat dengan jalan melakukan edukasi formal maupun non formal. Dalam pandangan pemakalah bahwa dimasyarakat bukan hanya menyatukan perbedaan saja, melainkan cara padangan serta cara berfikir atas perbedaan tersebut yang disamakan frekwensinya dengan pemahaman narasi sama. Sehingganya perbedaan yang ada di masyarakat dalam suatu wilayah dapat dirasakan sebagai kekayaan serta kekuatan untuk membangun masyarakat yang berperadaban dengan memaksimalkan potensi yang ada.

Multikultural sendiri merupakan satu ide yang telah lama dikaji dan dibahas oleh para cedikiawaan. Menjelaskan bahwa multikultural pada dasarnya adalah pandangan dunia yang kemudian dapat diterjemahkan dalam berbagai kebijakan kebudayaan yang menekankan tentang penerimaan terhadap realitas keagamaan, pluralitas, dan multikultural yang terdapat dalam kehidupan masyarakat.

Ada tiga ketegori dari konsep multikulturalisme: 1). Perbedaan subkultur (subculture divesity), yaitu individu atau sekompok masyarakat yang hidup dengan cara pandang dan kebiasaan yang berbeda dengan komunitas besar dengan sistem nilai atau budaya pada umumnya yang berlaku. 2). Perbedaan dalam perspektif (perspectival diversity) yaitu individu atau kelompok dengan perspektif kritis terhadap mainstream 
nilai atau budaya mapan yang dianut oleh mayoritas masyarakat di sekitarnya. 3). Perbedaan komunalitas (communal diversity), yakni individu atau kelompok yang hidup dengan gaya hidup yang genuine sesuai dengan identitas komunal mereka (indigeneous people way of life) (Bhikhu Parekh, 2000: 94).

Sebagaimana pengertian multikultural di atas dapat dipahami bawah multikultural adalah keragaman sosial budaya yang terjadi ditengah-tengah masyarakat yang diharapkan dengan perbedaan tersebut menjadi kekuatan untuk melahirkan kekompakan serta menghidarkan dari konflik di tengah masyarakat. Dalam pandangan multikultural, keragaman yang ada di masyarakat menjadikan lingkungan dan suasana interaksi yang menggerakan terbangunnya pemikiran kritis untuk kepentingan bersama terhadap persoalan-persoalan kehidupan di masyarakat.

Dalam kehidupan bermasyarakat, multikultural merupakan modal besar untuk mewujdkan masyarakat yang berperadaban, maju dan berkembang dalam upaya melahirkan masyarakat kuat, sejahteraan dan berkeadilan. Masyarakat multikultural merupakan sebuah komunitas masyarakat yang memiliki latar belakang budaya yang berbeda-beda antara satu dengan lainnya yang digabung menjadi satu dan saling menganut budayanya masing-masing. Masyarakat multikultural adalah masyarakat yang terdiri atas dua atau lebih komunitas (kelompok) yang secara kultural dan ekonomi terpisah-pisah serta memiliki struktur kelembagaan yang berbeda-beda satu sama lainnya.

Masyarakat multikultural adalah suatu masyarakat yang terdiri dari beberapa macam kumunitas budaya dengan segala kelebihannya, dengan sedikit perbedaan konsepsi mengenai dunia, suatu sistem arti, nilai, bentuk organisasi sosial, sejarah, adat serta kebiasaan ("A Multicultural society, then is one that includes several cultural communities with their overlapping but none the less distinc conception of the world, system of meaning, values, forms of social organizations, historis, customs and practices" (Bhikhu Parekh, 2000: 98)

Masyarakat multikultural harus memperoleh kesempatan yang baik untuk menjaga dan mengembangkan kearifan budaya lokal mereka ke arah kualitas dan pendayagunaan yang lebih baik. Unsur-unsur budaya lokal dapat bermanfaat bagi individu bahkan perlu dikembangkan lebih lanjut agar menjadi kebudayaan bangsa, memperkaya khazanah kebudayaan nasional. Misi pokok yang terkandung adalah mentransformasikan kenyataan multikultural sebagai aset dan sumber kekuatan bangsa menjadikannya 
sebagai sinergi nasional, memperkokoh aktivitas konvergensi keanekaragaman suatu bangsa (Munadlir, 2016: 24).

Pada masyarakat multikultural diperlukan penumbuhan pola pikir yang dilandasi oleh prinsip mutualisme, kerjasama sinergis saling menghargai dan memiliki (shared interest) dan menghindarkan pola pikir persaingan tidak sehat yang menumbuhkan eksklusivisme, namun sebaliknya, perlu secara bersama-sama berlomba meningkatkan daya saing dalam tujuan peningkatan kualitas sosial-kultural sebagai bangsa (Afandi, Munif, 2018:12).

Dengan multikultural akan menjadikan setiap orang sadar akan keberadaannya serta memahami apa yang harus di kerjakan dalam kehidupan masyarakat. Ketika semua masyarakat terpapar pemahaman multikultural maka pondasi nilai-nilai kebersamaan, kerjasama, keadilan, kemajemukan, perbedaan, gotong royong, kepedulian dengan sendirinya akan menjadi kebudayaan dan menjadi kebutuhan manusia dalam hubungan sosial.

\section{c. Sekolah Multikultural}

Pembumian wacana multikulturalisme pada ranah pendidikan formal (sekolah) dewasa ini semakin menggeliat. Maraknya gagasan multikulturalisme disertai dengan penyebaran isu pendahuluan: banyaknya peristiwa bentrokan dan konflik horizontal di tengah masyarakat. Berbagai pihak kemudian menyuarakan gagasan ini lebih keras dan diimplementasikan lebih dini dalam kurikulum pendidikan (Lasijan, 2014: 32).

Keragaman budaya, adat istiadat dalam perjalanannya kehidupan telah memberikan sumbangan terbesar dalam munculnya berbagai ketegangan dan konflik ditengan masyarakat. Sehingga tidak pelak lagi bahwa multikultural yang seharusnya menjadi modal sosial (social capital), justru menjadi kontraproduktif bagi terwujudnya tatanan kehidupan yang toleran, damai dan harmoni dengan tetap memiliki indentitas dalam mengikat kekuatan dalam dalam masyarakat. Keragaman budaya serta istiadat akan terlihat sangat jelas dalam interaksi sekolah sebagai salah satu wadah memproses pendidikan secara formal.

Sekolah merupakan suatu lembaga yang mengelola dan menyelenggarakan pendidikan dan pengajaran kepada peserta didik dalam usaha mencapai tujuan yang diharapkan serta merupakan tempat yang ampuh dalam membangun kecerdasan, sikap dan ketrampilan peserta didik dalam menghadapi realita kehidupannya. Di sekolah terjadi interaksi antar warga sekolah dengan cepat yang terjaga kontinuitas waktunya, dengan 
demikian sekolah adalah tempat berjalannya proses multikultural dengan sendirinya tanpa kita sadarai.

Dalam konteks keragaman, multikultral memerlukan pemikiran dan perlakukan sercara serius serta berkesinambungan dalam penangan agar tidak menimbulkan masalah atas perbedaan ditengah-tengah masyarakat. Maka dalam hal ini perlu rasanya menyadarkan untuk menjada komitmen dalam multikulturalisme yang menjadi idetitas bersama dalam interaksi dalam masyarakat. Dalam hal ini sekolah menjadikan wadah yang tepat untuk melakukan edukasi serta pendampingan dalam upaya mendorong pemahaman dan kesadaran masyarakat menggunakan hak konstitusinya dalam berkumpul, berserikat dan berpendapat guna memperjuangkan hak-hak keadilan, kesetaraan, kebebasan dan berpartisipasi dalam masyarakat dengan basis multikulturalisme.

Sekolah dalam padangan stratergi pembelajaran merupaya upaya dan usaha yang ampuh dalam menghidupkan serta mengembangkan pendidikan multikultural. Maka kiranya sekolah mulitkultural juga harus diusahakan dalam menjawab dan meminimalisir segala macam konflik dan persoalan di tengan masyarakat. Sehingga sekolah multkultural dapat dilihat dari pembelajarannya mengintegrasikan nilai-nilai pendidikan multikultural dalam mata pelajaran.

Sekolah multikultural dapat dilihat dan difahmi seperti yang di sampaikan Maksum dan Ruhendi tentang ciri-ciri pendidikan multikultural mempunyai ciri-ciri sebagai berikut: 1). Tujuannya untuk membentuk "manusia budaya" dan menciptakan "masyarakat berbudaya (berperadaban)". 2). Materinya mengajarkan nilai-nilai luhur kemanusiaan, nilai-nilai bangsa, dan nilai-nilai kelompok etnis (kultural). 3). Metodenya demokratis yang menghargai aspek-aspek perbedaan dan keragaman budaya bangsa dan kelompok etnis (multikulturalis). 4). Evaluasinya ditentukan pada penilaian terhadap tingkah laku anak didik yang meliputi: persepsi, apresiasi, dan tindakan terhadap budaya lainnya (Maksum, A. dan Ruhendi, L.Y, 2009: 78).

Maka penting kiranya sekolah sebagai lembaga pendidikan berperan dalam mengembangkan kemampuan peserta didik dalam usaha memiliki pengetahuan, sikap serta tidakan yang mampu menghadapi dan menjalani realita kehidupan yang berkemajuan, berkeadilan dan menetramkan yang didasakan pada perbedaan multikultur dan multi etnis. Sekolah multikulrutal menghadirkan pembelajaran dalam pendampingan proses pengembangan seluruh potensi peserta didika yang menghargai pluralitas dan 
hiterogenitasnya sebagai konsekuensi keragaman agama, suku, budaya dan etnis. Dengan demikian sekolah menjelma sebagai lembaga pendidikan mutlikultural menghendaki penghormatan dan penghargaan setinggitingginya terhadap harkat dan martabat manusia dari mana pun dia datangnya dan berbudaya apa pun dia. Harapannya adalah tercipta kedamaian sejati, keamanan yang tidak dihantui kecemasan dan kebahagiaan tanpa rekayasa (Ainurrafiq Dawam, 2003: 54).

Sekolah multikulural bertugas untuk memberikan bekal pengetahuan, keterampilan dan kemampuan yang diperlukan seseorang agar ia dapat menapaki perjalanan kedewasaannya secara utuh dan tersalurkannya bakat-bakat potensial yang ia miliki. Di tengah masyarakat sekolah multikultural menghadirkan pendidikan yang bermanfaat bagi kelangsungan dan proses kemajuan hidupnya. Agar masyarakat itu dapat melanjutkan eksistensinya, maka kepada anggota mudanya harus diteruskan nilai-nilai, pengetahuan, keterampilan, dan bentuk tata perilaku lainnya yang diharapkan akan dimiliki oleh setiap anggota. Setiap masyarakat berupaya meneruskan kebudayaannya dengan proses adaptasi tertentu sesuai corak masing-masing periode jaman kepada generasi muda melalui pendidikan, secara khusus melalui interaksi sosial. Dengan demikian pendidikan dapat diartikan sebagai proses sosialisasi.

Sekolah multikultural akan melahirkan prilaku kolektivitis ditengah masyarakat, di dalamnya kita akan menemukan masyarakat yang diikat dengan kokoh, tingginya rasa kebersamaan, tidak ada batas dalam keluarga besar, terjadi ketulusan loyalitas tanpa pamrih. Tidak akan ada makna politik dengan prilaku kolektivitisme, semua akan dikerjakan dengan semata-mata kebersamaan dalam kelompok.

Sekolah multikultural dengan sendirinya akan melahirkan kultur sekolah yang positif, berdampak pada kemajuan sekolah. Adapun kultur sekolah yang baik antara lain muncul dalam bentuk : (1) kesetiakawanan, (2) kebiasaan mencoba hal-hal yang baru, (3) memiliki harapan prestasi yang tinggi dan kerja keras untuk mewujudkan prestasi itu, (4) saling percaya mempercayai, (5) memberikan dukungan tiil pada kolega, (6) bertindak berdasarkan pengetahuan, (7) saling mengapresiasi dan menghormati, (8) saling memberikan perhatian, merayakan bersama akan keberhasilan, (9) warga sekolah terlibat dalam megambil keputusan, (10) senantiasa menjaga apa-apa yang penting, (11) jujur, memiliki komunikasi yang terbuka, dan yang amat penting adalah semua warga, khusunya setiap siswa memiliki cita-cita mau jadi apa di masa depan (Zamroni, 2016: $62)$. 
Berangkat dari sinilah bahwa sekolah dalam pandangan multikultural bukan saja menjadi lembaga pendidikan yang hanya mentransfer ilmu (knowledge), melain juga menanamkan prilaku kebaikan berdasarkan agama (Akhlakul Karimah) maka sekolah juga menjadi agen dalam memberikan pehaman keagamaan serta membangun prondasi kuat terhadap kebaikan prilaku. Yang selanjutnya sekolah multikulrutal juga membangu jiwa sosial kemanusiaan, dari sini sekolah juga memberikan sumbangsih dalam memelihara kerukunan antara masyarakat dan memberikan pelayanan pada teman sebaya.

Terakhir sekolah multikultural menempuh langkah-langkah dengan mengembangkan model pembelajaran multikultural sebagai berikut: (1) Guru mereduksi atau mengikis sikap negatif yang mungkin mereka miliki terhadap pluralisme sosial, keagamaan, dan etnis. (2) Seorang pendidik dan anak didik melakukan analisa terhadap situasi agar akrab dengan masyarakat. (3) Seorang pendidik dan anak didik memilih materi yang relevan dan sekaligus menarik. (4) Seorang pendidik dan anak didik, bersama-sama, menyelidiki persoalan yang berkaitan dengan materi yang dipilih.

Dari sini sekolah multikultural memiliki identitas tersendiri yaitu memeran semua perserta didik dalam proses belajar mengajar, dan guru memiliki kekampuan untuk melakukan hal-hal yang menarik yang inovatif yang menjadikan ruang belajar lebih hidup karena semua siwa terlibat aktif. Dan guru disini membangun kersamaan dengan pemahaman dan keadaan siswa sehingga kedekatan antara guru dan siswa terbangun karena proses pembelajaran yang menarik dan juga saling membutuhkan.

\section{d. Merawat Masyarakat Multikultural}

Skema kehidupan masyarakat tentunya akan ada usaha meningkatkan taraf keilmuan masyarakat. Usaha peningkatkan keilmuan di masyarakat tentunya harus juga disesuaikan dengan perkembangan zaman, harus pula di dampingi dengan beberapa keilmuan. Meningkatkan keilmuan secara maksimal di masyarakat perlu adanya sebuah majlis yang dimana terjadi proses sosialisasi keilmuan secara jelas. Akan akan terjadi pertukaran dari berbagai sumber yang dipastikan kejelasanny. Paling utama adalah meningkatkan keilmuanya di bidang keagamaan dan tentunya kemaysarakatan, dengan pendekatan pendidikan multikulural dapat dijadikan bekal utama dalam menjalani kehidupan bermasyarakat kedepan (Furqon, 2021: 94).

Dalam masyarakat multikultural seperti Indonesia, pemahaman timbal balik sangat dibutuhkan, untuk mengatasi hal-hal yang negatif dari suatu masalah integrasi bangsa. 
Paradigma hubungan timbal balik dalam masyarakat multikultural mensyaratkan tiga kompetensi normatif, yaitu kompetensi kebudayaan, kemasyarakatan dan kepribadian. Kompetensi kebudayaan adalah kumpulan pengetahuan yang memungkinkan mereka yang terlibat dalam tindakan yang komunikatif. Kompetensi kemasyarakatan merupakan tatanan-tatanan yang memungkinkan mereka yang terlibat dalam tindakan komunikatif membentuk solidaritas. Kompetensi kepribadian adalah kompetensi yang memungkinkan seseorang dapat berbicara dan bertindak dan mampu berpartisipasi dalam proses pemahaman timbal balik sesuai konteks tertentu dan mampu memelihara jati dirinya sendiri dalam berbagai perubahan interaksi (Zaenal Abidin, 2016: 89).

Pada dasaranya pendidikan merupakan jalan untuk menjadikan manusia memiliki adab dalam kehidupan masyarakat. Dengan pendidikan masyarakat diharapakan memiliki kesadaran akan pentingnya berprilaku yang baik selain pendidikan juga mengusahakan peserta didik memiliki kemampuan dalam memahami nilai-nilai ketuhanan, kemanusia, persatuan, kebersamaan serta nilai-nilai keadilan. Maka dari sini pendidikan multikultural sebenaranya tidak hanya mengubah kecerdasn kognitif saja melainkan kecersan afektif serta kecerdasan psikomotor.

Pendidikan juga diharapkan untuk memupuk rasa taqwa kepada Tuhan Yang Maha Esa, meningkatkan kemajuan-kemajuan dan pembangunan politik, ekonomi, sosial, pertahanan keamanan serta keagamaan itu sendiri. Pendidikan dalam dimensi kehidupan secara menyeluruh dapat diharapkan untuk mengembangkan wawasan anak terhadap ideologi, politik, ekonomi, sosial, budaya dan pertahanan keamanan secara tepat dan benar, sehingga membawa kemajuan dan keadaban pada individu masyarakat dan negara untuk mencapai tujuan pembangunan nasional.

Adapun fungsi pendidikan dalam masyarakat (1) Fungsi sosialisasi, (2) Fungsi kontrol sosial, (3) Fungsi pelestarian budaya Masyarakat, (4) Fungsi latihan dan pengembangan tenaga kerja, (5) Fungsi seleksi dan alokasi, (6) Fungsi pendidikan dan perubahan sosial, (7) Fungsi reproduksi budaya, (8) Fungsi difusi kultural, (9) Fungsi peningkatan sosial, dan (10) Fungsi modifikasi sosial (Abdullah Idi, 2011: 55).

Jika kita membaca dan memahami apa yang disampaikan di atas maka terlihat jelas bahwa pendidikan multikultural akan membawa perubahan terhadap cara fikir, cara pandangan serta cara prilaku masyarakat. Perubahan itu adalah cerdasnya masyarakat dalam menyikapi berbagai persoalan jika dapat sentuhan pendidikan multikultural dan multikulturalisme. 
Dalam kaitan hal ini juga dalam merawat masyarakat multikultural juga dapat menggunakan paradigma pendidikan multikultural. Sebagaimana disampaikan oleh paradigma pendidikan multikultural perlu mewarnai model pembelajaran yang diterapkan dalam kelas. Model pembelajaran multikultural tersebut menggunakan berbagai pendekatan berbeda-beda. Misalnya, seorang guru menyajikan bahan termasuk dalam memberi contoh, dia dituntut memilih yang beraneka nilai. Di samping itu, bukubuku yang ditulis dalam pelajaran pun perlu disusun untuk menghargai budaya lain dan penghargaan jender.

Menurut Bloom, multikulturalisme meliputi sebuah pemahaman, penghargaan dan penilaian budaya seseorang dan sebuah penghormatan dan keingintahuan tentang budaya etnis orang lain. Meski demikian, sebuah penilaian terhadap kebudayaan-kebudayaan orang lain bukan dalam arti menyetujui seluruh aspek dari kebudayaan-kebudayaan orang lain tersebut, melainkan mencoba melihat bagaimana kebudayaan tertentu dapat mengekspresikan nilai bagi anggota-anggotanya sendiri.

Dengan demikian multikulturalisme sebagai sebuah paham menekankan pada keseteraan budaya lokal tanpa mengabaikan hak-hak, kewajiban dan eksistensi budaya yang ada. Konsep multikulturalisme mengulas berbagai permasalahan yang mendukung ideologi, politik, demokrasi, keadilan, penegakan hukum, kesempatan kerja dan usaha, hak asasi manusia, hak budaya komuniti dan golongan minoritas, prinsip-prinsip etika dan moral, tingkat serta mutu produktivitas serta berbagai konsep lainnya yang relevan sehingga mulitkulural akan menjadi nilai utama dalam masyarakat.

Salah satu persoalan yang sering terjadi dimasyarakat dalam merawat multikultural adalah dalam memandang agama dan budaya. Di sisi lain, menguatnya gejala globalisasi yang berakibatkan pada derasnya arus hegemoni budaya barat yang akan memudarkan nasionalisme setiap generasinya. Maka akan menjadi penting jika kita dapat merevatilisai pandangan agama dan budaya. Ada beberapa cara yang dapat dipakai dalam memandang hubungan agama dan budaya, hubungan keberagamaan dan kebudayaan (Haidar Bagir, 2017: 64). Pertama, melihat agama sebagai mengharagai budaya sebagai sumber kearifan (QS. Al Hujarat:13). Kedua, melihat budaya sebagai warisan hikmah ketuhahan yang diturunkan lewat nabi-nabi yang pernah ditus Tuhan sepanjangan sejarah umat manusia (QS. Yunus: 47).

Dari pemaparan di atas maka jelaslah bawah masyarakat multikultural ini harus terus dirawat dalam rangka menjaga eksistensi masyarakat dari perwujudkan 
kemanusiaan dan secara nilai illahiyah merawat adalah bentuk dari kesyukuran. Pendidikan multikultural hadir dan dilibatkan dengan cara diintegrasikan dalam pembelajaran dikelas dengan harapan bahwa proses pendidikan lebih dimanis, humanis dan moderat. Pendidikan yang mengedepan perbedaan adalah sebuah kelebihan dari satu kelompok serta menjadi motivasi dalam melakukan inovasi dan kreatifitas dalam proses pembelajaran.

Dengan adanya pemahaman dan pendidikan multikulturalisme, memungkinkan akan terwujudnya komunikasi lintas budaya. Artinya adanya keinginan untuk saling mengenal antara budaya yang satu dengan budaya yang lainnya, sehingga hal ini akan mengurangi gesekan-gesekan yang ditimbulkan dari perbedaan-perbedaan yang ada di dalam membangun dan mengembangkan potensi yang ada dalam kehidupan berbangsa dan bernegara.

\section{KESIMPULAN}

Dari apa yang telah dibahas maka dapat disimpulkan: Pertama, dengan pendidikan multikultural dalam konteks kemasyarakatan maka akan tercipta masyarakat yang dengan sendirinya bersedia menerima kelompok lain secara sama sebagai kesatuan, menghormati dan menghargai perbedaan budaya, etnis, gender, bahasa, ataupun agama. Kedua, dengan merawat masyarakat multikultural dapat dikaji menggunakan paradigma pendidikan multikultural sehingga akan terlahir masyarakat yang kritis, peka dengan keadaan serta meningkatnya kepeduliaan sosial sebagai upaya kesatuan yang integrative. Ketiga, masyarakat multikultural merupakan modal besar yang dimiliki bangsa Indonesia untuk menjaga persatuan dan meminimalisir masyarakat yang intoleran, terjadinya radikalisnya dan menjegah lahirnya terorisme ditengah masyarakat. Keempat, dengan pendidikan multikultural memberikan pemahaman bahwa keberagaman dalam masyarakat tidak dilebur dalam satu wadah dengan identitas baru, melainkan masing-masing individu yang berbeda diberi kesempatan yang sama untuk berekspresi, berkembang, dan berinteraksi di tengah masyarakat, yang hal itu diwujudkan dalam suatu ikatan komitmen moral untuk saling menghargai dan toleransi.

\section{DAFTAR PUSTAKA}

A. Fuad Fanani. (2004). Islam Mazhab Kritis: Menggagas Keberagamaan Liberati. Kompas Gramedia.

Abdullah Idi. (2011). Sosiologi Pendidikan. Raja Grafindo Persada. 
Abu Ahmadi,. (2009). Ilmu Sosial Dasar (p. 6). Rineka Cipta.

Afandi, Munif,. (2018). Potret Masyarakat Multikultural Di Indonesia,. Journal Multicultural Of Islamic Edication, 2, 12.

Ainurrafiq Dawam. (2003). Emoh Sekolah (p. 54). Inspeal ahisma Karya Press.

Bhikhu Parekh. (2000). Rethingking Multiculturalism: Cultural Diversity and Political Theory. Harvard University Press.

Furqon, F. (2021). Peran Manusia di Bumi Sebagai Khalifah Dalam Perubahan Sosial. An Naba, 4(1), 1-13. https://doi.org/10.51614/annaba.v4i1.66

Haidar Bagir. (2017). Islam Tuhan, Islam Manusia (p. 64). Penerbit Mizan.

Lasijan. (2014). Multikulturalisme Dalam Pendidikan Islam. Jurnal TAPIs, 10, 26.

M. Ainul Yaqin. (2005). Pendidikan Multikultural: Cross-Cultural Understanding untuk Demokrasi dan Keadilan (p. 3). Pilar Media, 2005.

Maksum, A. dan Ruhendi, L.Y. (2009). Paradigma Pendidikan Universal,. IRCSod).

Munadlir, A. (2016). STRATEGI SEKOLAH DALAM PENDIDIKAN MULTIKULTURAL. JURNAL JPSD (Jurnal Pendidikan Sekolah Dasar), 2(2), 114. https://doi.org/10.26555/jpsd.v2i2.a6030

Nur Syam. (2009). Tantangan multikulturalisme Indonesia: Dari radikalisme menuju kebangsaan, (). Kanisius.

Nurani Soyomukti. (2010). Pengantar Sosiologi. Ar Ruzz Media.

Paulo, F. (1984). Pendidikan Sebagai Praktek Pembebasan, $t$ (Terj. Alois A. Nugroho, p. 102). Gramedia.

Soerjono Soekanto,. (2012). Sosiologi Suatu Pengantar (p. 36). Rajawali.

Stella Rose Que. (2017). Masyarakat Multikultural Dalam Cerminan Budaya Populer Amerika Dan Indonesia. Jurnal Tahuri, 14, 87.

Zaenal Abidin. (2016). MENANAMKAN KONSEP MULTIKULTURALISME DI INDONESIA. 01, 18.

Zamroni. (2016). Kultur Sekolah. Gavin Kalam Utama. 